Article

\title{
The Use of Aerial RGB Imagery and LIDAR in Comparing Ecological Habitats and Geomorphic Features on a Natural versus Man-Made Barrier Island
}

\author{
Carlton P. Anderson 1,2,*, Gregory A. Carter ${ }^{1,2}$ and William R. Funderburk ${ }^{1,2}$ \\ 1 Department of Geography and Geology, University of Southern Mississippi, Long Beach, MS 39561, USA; \\ greg.carter@usm.edu (G.A.C.); william.funderburk@usm.edu (W.R.F.) \\ 2 Gulf Coast Geospatial Center, University of Southern Mississippi, Long Beach, MS 39560, USA \\ * Correspondence: carlton.p.anderson@usm.edu; Tel.: +1-228-234-4067
}

Academic Editors: Richard W. Gould Jr., Deepak R. Mishra and Prasad S. Thenkabail

Received: 17 March 2016; Accepted: 12 July 2016; Published: 16 July 2016

\begin{abstract}
The Mississippi (MS) barrier island chain along the northern Gulf of Mexico coastline is subject to rapid changes in habitat, geomorphology and elevation by natural and anthropogenic disturbances. The purpose of this study was to compare habitat type coverage with respective elevation, geomorphic features and short-term change between the naturally-formed East Ship Island and the man-made Sand Island. Ground surveys, multi-year remotely-sensed data, habitat classifications and digital elevation models were used to quantify short-term habitat and geomorphic change, as well as to examine the relationships between habitat types and micro-elevation. Habitat types and species composition were the same on both islands with the exception of the algal flat existing on the lower elevated spits of East Ship. Both islands displayed common patterns of vegetation succession and ranges of existence in elevation. Additionally, both islands showed similar geomorphic features, such as fore and back dunes and ponds. Storm impacts had the most profound effects on vegetation and geomorphic features throughout the study period. Although vastly different in age, these two islands show remarkable commonalities among the traits investigated. In comparison to East Ship, Sand Island exhibits key characteristics of a natural barrier island in terms of its vegetated habitats, geomorphic features and response to storm impacts, although it was established anthropogenically only decades ago.
\end{abstract}

Keywords: barrier island; aerial imagery; LIDAR; elevation; micro-topography; habitat change; vegetation; geomorphic change; Gulf of Mexico

\section{Introduction}

Barrier islands front approximately $10 \%$ of the world's open-ocean shorelines, with $35 \%$ of those barrier islands in North America [1-4]. They facilitate resiliency in coastal ecosystems by buffering mainland shores from storms and daily wind and wave energies. However, barrier island ecosystems are susceptible to saltwater intrusion with continuing sea-level rise due to their low elevation, presumably making them reliable markers of global climate change [3,5]. It has been generally accepted that the presence of a freshwater lens indicates the overall sustainability of a barrier island and drives habitat development [6,7]. With access to fresh water, bare sand is colonized by pioneering species, leading to foredune growth and gradual transitions to shrubland and maritime forest $[3,8,9]$. On barrier islands in the northern Gulf of Mexico, the extent of total land area and drier habitat types, which form at higher elevations, such as shrubland and woodland, is declining relative to lower-elevation, wetter habitat types, such as marsh, at a time scale of a few decades $[3,10,11]$. This appears to be a combined effect of relative sea level rise and navigational shipping channels impeding natural littoral drift, ultimately affecting sediment replenishment along these islands [11]. In order to better 
understand the natural and anthropogenic effects on succession pathways, short-term succession in these environments needs to be better understood. A better understanding of sub-decadal vegetation succession on these islands would yield an improved perspective on these recently-documented, decadal-scale trends.

The Mississippi (MS) barrier island chain (Figure 1) is comprised of several naturally-formed islands (Cat, East and West Ship, Horn and Petit Bois) plus one island (Sand) that was created over recent decades through artificial deposition of dredge material from navigation channels. The natural barriers are thought to have formed from the slowing of sea-level rise during the Holocene Transgression [12]. Their habitats and especially geomorphic features have been studied since the early and mid-20th century [3,5,8-13]. However, to our knowledge, no prior research on the MS islands has focused on short-term habitat and geomorphic change on man-made versus naturally-formed islands. Of particular interest was a comparison between Sand and East Ship because their land areas are similar and least among the Mississippi barrier islands.

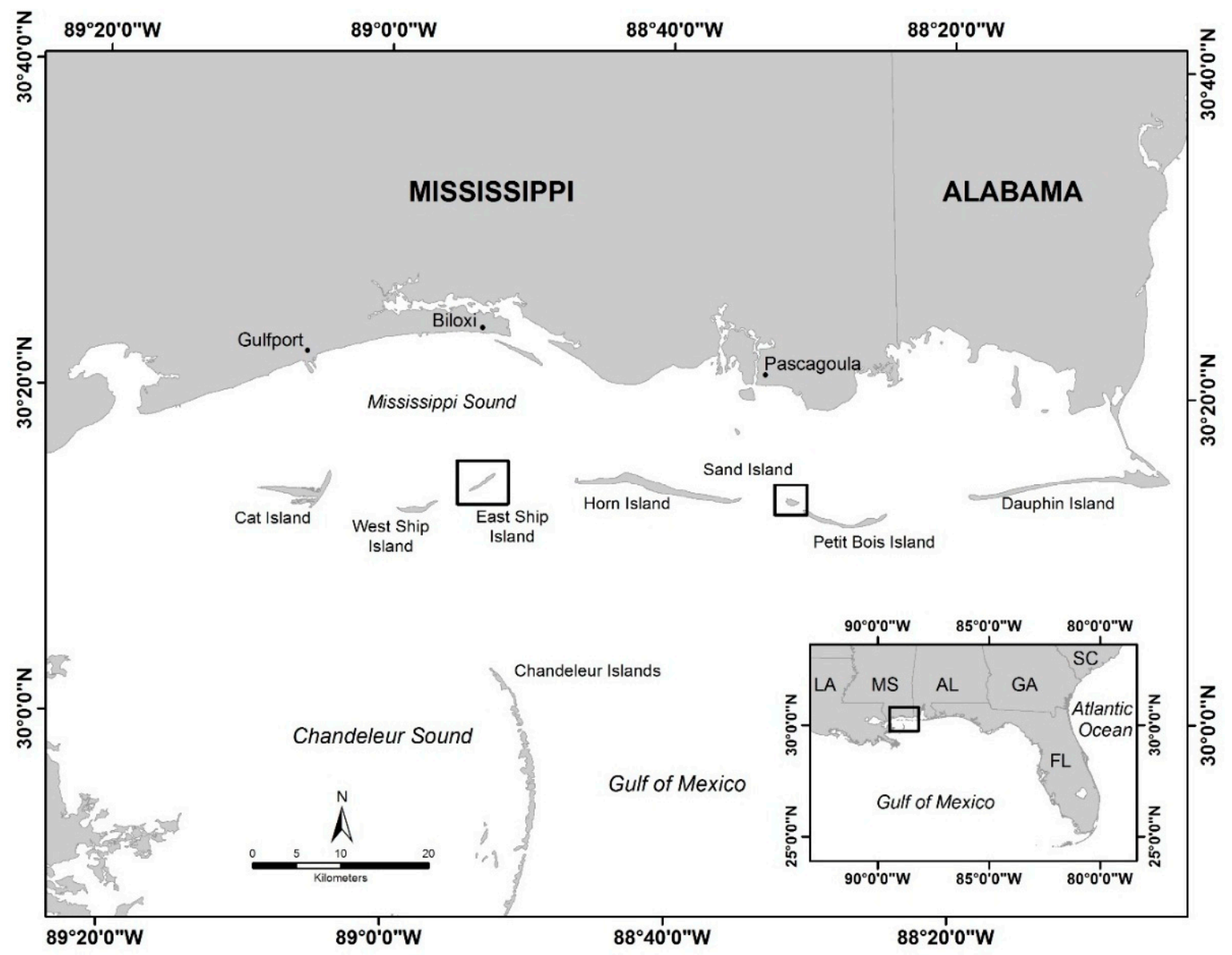

Figure 1. The MS barrier island chain, USA, showing the East Ship and Sand Island study sites.

The purpose of the present study was to: (1) compare habitat type composition, geomorphic features and elevation between East Ship and Sand Island; and (2) evaluate the extent to which habitat types changed on the two islands over a time period of less than one decade. Remotely-sensed and ground data were used to determine habitat type coverage, elevation and land area of each island and their extent of change from summer 2007 to summer 2012. 


\section{Materials and Methods}

\subsection{Study Area}

East Ship Island, initially formed ca. $4.5 \mathrm{ka}{ }^{14} \mathrm{C}$ [14], is located approximately $15 \mathrm{~km}$ south of the Mississippi mainland shore $\left(30^{\circ} 14^{\prime} 13^{\prime \prime} \mathrm{N},-88^{\circ} 53^{\prime} 13^{\prime \prime} \mathrm{W}\right)$. The island is composed mostly of quartz sand with finer silts and clays on its lagoonal side. As of 2012, it was approximately $3.5 \mathrm{~km}$ in length $(\mathrm{E}-\mathrm{W})$ and $400 \mathrm{~m}$ wide (N-S). The island is characterized by two low elevation $(<0.5 \mathrm{~m})$ east and west spits extending from a higher elevation $(>0.5 \mathrm{~m})$ central core. The core, which has remained relatively intact through multiple historical tropical storms, has been the most stable portion of the island [15]. The east and west spits support mainly beach grasses and algal flats [15]. The core includes a tidally-influenced pond, with muddy peat soils and relict dune ridges vegetated with beach morning glory (Ipomoea imperati (Vahl) Griseb.), salt meadow cordgrass (Spartina patens (Aiton) Muhl.), marsh elder (Baccharis halimifolia L.), saw palmetto (Serenoa repens (W. Bartram) Small) and sand live oak (Quercus geminata Small). East Ship is currently managed by The National Park Service (NPS), Gulf Islands National Seashore (GUIS).

Disposal Area 10, known locally as Sand Island, is located approximately $11 \mathrm{~km}$ off the Mississippi mainland shore $\left(30^{\circ} 13^{\prime} 26^{\prime \prime} \mathrm{N},-88^{\circ} 31^{\prime} 19^{\prime \prime} \mathrm{W}\right)$ on the western edge of the Pascagoula ship channel and is approximately $1.7 \mathrm{~km}$ in length (E-W) and $580 \mathrm{~m}$ in width (N-S). The island began formation in the 1960s from an underwater shoal created through the deposition of dredge material from the neighboring Pascagoula ship channel [12]. The island emerged around 1971 through channel maintenance and the natural reworking of the ebb-tidal sediment, combined with deposition from littoral drift $[11,16,17]$. Notably, among the islands in the chain, Sand has the highest elevation of approximately $9 \mathrm{~m}$ North American Vertical Datum 1988 (NAVD88). It is composed mostly of quartz sand mixed with calcareous shell fragments. The island is geomorphically characterized by highly-elevated east-west recurved and truncated beach ridges [11,16]. As with East Ship, Sand has a stable core supporting a freshwater pond and vegetated habitats. Vegetation includes wax myrtle (Morella cerifera Small), sea oat (Uniola paniculata L.), gulf bluestem (Schizachyrium maritimum (Chapm.) Nash) and salt meadow cordgrass. The region has a humid subtropical climate with mean air temperatures of $12{ }^{\circ} \mathrm{C}$ and $27^{\circ} \mathrm{C}$ in the winter and summer, respectively. Peak rainfall occurs in July through September with mean annual amounts of approximately 140-160 cm [18].

From 2007-2012, two tropical events affected the study area with sustained winds $>20 \mathrm{~m} / \mathrm{s}$ [19,20]. Hurricanes Gustav (1 September 2008) and Isaac (29 August 2012) both passed to the west of the MS islands on similar northwesterly tracks. According to Beven and Kimberlain [20], storm tides for Hurricane Gustav were $2.03 \mathrm{~m}$ at Point Cadet in Biloxi, Mississippi $\left(30^{\circ} 23^{\prime} 23^{\prime \prime} \mathrm{N},-88^{\circ} 51^{\prime} 28^{\prime \prime} \mathrm{W}\right)$ and $2 \mathrm{~m}$ at the Port of Pascagoula $\left(30^{\circ} 20^{\prime} 43^{\prime \prime} \mathrm{N},-88^{\circ} 34^{\prime} 02^{\prime \prime} \mathrm{W}\right)$. Wind gusts of approximately $30 \mathrm{~m} / \mathrm{s}$ were also reported in these areas during Gustav. In 2012, Hurricane Isaac produced storm tides of $2 \mathrm{~m}$ at Point Cadet and $1.81 \mathrm{~m}$ at the Port of Pascagoula [20]. Wind speeds were slightly higher than Gustav's at these sites, with gusts $>32 \mathrm{~m} / \mathrm{s}$. Hurricane Isaac was very similar to Gustav with respect to wind, storm tides, trajectory and total projected area; however, Isaac's forward speed was hindered due to a mid-level blocking ridge northwest of the storm $[19,20]$.

\subsection{Remote Sensing and Ground Data}

Remotely-sensed data products for this investigation included: (1) United States Department of Agriculture (USDA), National Agriculture Imagery Program (NAIP) high-resolution, (1 m) RGB (blue: 400-580 nm, green: 500-650 nm and red: 590-675 nm) aerial imagery collected in 2007, 2009, 2010 and 2012 (East Ship in August 2007, 2009, 2010 and September 2012; Sand in August 2007, June 2009, May 2010 and September 2012); (2) LEICA, model ALS 60 multiple-return topographic near-infrared (1064 $\mathrm{nm})$ LIDAR ( $\pm 4 \mathrm{~cm}$ horizontal and $\pm 14 \mathrm{~cm}$ vertical accuracies), at a 1 -m point density sampling (October 2012, Galileo Group, Inc., Melbourne, FL, USA). Ground datasets for this project included 
a 2010 GPS coordinate habitat type database containing primary and secondary species information with cardinal-directional photos.

NAIP imagery was used because it is collected every two years [21]. Starting in 2012 for the state of Mississippi, NAIP imagery consisted of three visible (blue: 400-580 nm, green: 500-650 nm and red: 590-675 $\mathrm{nm}$ ) and one near infrared $(675-850 \mathrm{~nm})$ band. However, prior to 2012, NAIP imagery acquired in Mississippi did not collect near-infrared. Thus, this study employed the blue, green and red bands for all analyses to ensure image comparability between years. Image data were comprised of a Brightness Value (BV) (0-255) referenced to NAD83 and projected in Universal Transverse Mercator (UTM) Zone 16 North [21]. All NAIP imagery was post-processed and quality checked by the data collector. Post-processing included removal of bidirectional reflectance effects, vignetting and other artifacts [21].

The 2010 acquisition was chosen as the base image for both islands because ground data were collected in that year. BV histograms for each band (blue, green and red) and year were stretched to match the $2010 \mathrm{BV}$ histograms to correct for BV intensity differences and to provide a baseline for calibration to surface reflectance. Image BVs then were scaled to surface reflectance using the empirical line method (ENVI v4.3, Exelis Visual Information Solutions, Boulder, CO, USA). Assuming that island bare sand surface reflectance remains consistent year after year, Regions-of-Interest (ROI) consisting of 3000 bare-sand pixels were selected in each image to provide sample data for the empirical line method. In situ data used for this calibration were the spectral reflectance of beach sand, recorded using a portable spectroradiometer (ASD-FS, Boulder, CO, USA) on neighboring Horn Island. An image-to-image geometric registration was performed for all East Ship and Sand Island imagery. Images for 2007, 2009 and 2012 were georectified to 2010 with no less than 10 Ground Control Points (GCP) for each image with a total $\mathrm{RMS}_{\text {error }}<0.5$, as per the registration methods outlined by Jensen [22]. Due to the lack of anthropogenic features and hard targets on both islands, GCPs consisted of individual patches of vegetation that remained stable and identifiable in each image.

In 2010-2011, the Gulf Coast Geospatial Center conducted a field vegetation survey for the MS-AL barrier island chain [23]. Ground surveyed data were taken using randomly-selected points at a mean density of one point per 6 ha of island area. The method was based on Lucas and Carter's [24] previous study, which utilized a similar sampling density for line transects. Sample points were positioned randomly (ENVI v4.3) from SPOT-5 (10 m) Ground Sampling Distance (GSD) multispectral coverage (April-July 2010 image acquisitions, North American Data Purchase, USGS EROS Data Center, Sioux Falls, SD, USA). Geographic centers were then visited using a Trimble Geoexplorer 6000. If a sample point fell in a body of water, it was moved to the nearest above-water area. A range pole was then planted in the ground to mark the sample point location, and notes were made concerning primary and secondary vegetation species in the immediate area. Additionally, cardinal-directional photographs were taken at each point with the range pole being in the center of the field-of-view using a Nikon model D-60 SLR with a Nikon 18-55 mm f/3.5-5.6G VR AF-S DX lens, set at $18 \mathrm{~mm}$ to achieve the widest field-of-view [23]. Photographs were taken clockwise at magnetic compass headings of $0^{\circ}, 90^{\circ}, 180^{\circ}$ and $270^{\circ}$. Habitat classifications for each sampled location were then made through the visual inspection of photographs and documented primary and secondary species. The classification scheme was based on those used in the Mississippi Natural Heritage Program 2006 [25].

A geodatabase was constructed (ArcGIS v10.1, ESRI, Redlands, CA, USA) to house all sample point information. All point data share the same datum and projection as the NAIP imagery. Attribute fields for point data included site identification number, site visitation date, time, horizontal precision, geographic coordinates of the site, primary species, secondary species, general notes pertaining to the site and habitat classification type. Sample site photographs were attached as binary large objects in the geodatabase for data management and ease of use.

\subsection{Supervised Classification of Habitats}

The Maximum Likelihood (ML) supervised classifier was used because of its wide acceptance, and it has provided the greatest accuracy in comparison to other classifications used on the MS 
islands $[3,22,24,26]$. Classifications were created for East Ship and Sand Island initially for 2010 because the ground survey took place that year. The habitat classes used for East Ship Island were: algal flat (Salicornia sp. and matted organics), bare sand, beach dune herbland (sea oat, gulf bluestem, and beach morning glory), marsh shrubland (smooth cordgrass, wax myrtle, marsh elder and sand live oak) and water. The same classes were used for Sand Island, except it did not include algal flat. Sampled pixel data were generated from the 2010 ground survey GPS locations with habitat type information and photographs attached. Additionally, training data pixels (Table 1) were selected in 1-m ROI increments based on estimations from field photographs.

Table 1. Number of training pixels used in classifications.

\begin{tabular}{ccccc}
\hline \multicolumn{5}{c}{ East Ship Island } \\
\hline Habitat type & 2007 & 2009 & 2010 & 2012 \\
Algal flat (NE spit) & 153 & 154 & 300 & 105 \\
Algal flat (SW spit) & - & - & - & 100 \\
Bare sand (NE spit) & 2967 & 2,959 & 1512 & 2119 \\
Bare sand (SW spit) & - & - & - & 2008 \\
Bare sand (core) & 3192 & 2387 & 2600 & 1727 \\
Beach dune herbland & 310 & 188 & 229 & 444 \\
Marsh shrubland & 583 & 213 & 346 & 924 \\
Water & 2728 & 919 & 1013 & 1571 \\
\hline & Sand Island & & \\
\hline Habitat type & 2007 & 2009 & 2010 & 2012 \\
Bare sand & 1477 & 1514 & 1360 & 1005 \\
Beach dune herbland & 906 & 315 & 300 & 234 \\
Marsh shrubland & 302 & 309 & 271 & 267 \\
Water & 314 & 300 & 158 & 144 \\
\hline
\end{tabular}

To ensure classification of only island land areas, masks were created (ArcGIS v10.1) by digitizing shorelines (1:600 scale) for each island image. The idealized shoreline is very dynamic, requiring the use of shoreline indicators to determine the boundaries [27]. Thus, shorelines were visually interpreted by the discernable wet-to-dry sand interface. Any pixels outside of the masked shoreline for classifications were given the designation sub-aqueous. This differed from the water class in that the water habitat type (non-vegetated pond) fell within the shoreline boundaries. Sample pixel data were selected in 1-m increments for 2007, 2009 and 2012 images, based on mean surface percent reflectance threshold values from each habitat in the 2010 ML. Post-classification reports were generated, consisting of a confusion matrix to determine the overall accuracies and errors of commission and omission [22]. Commission errors represented the percentage of pixels that are assigned to a class, while belonging to another class. These errors apply to the training data used in the ML classification. Omission errors were represented by the percentage of pixels that should have been included in a class, but were not [28].

\subsection{Change Detection}

A post-classification change detection compared initial and final state classification maps on a pixel-by-pixel basis using Geographic Information System (GIS)-based raster algorithms (ENVI v4.8) to produce a change detection matrix [22,29]. Classifications assign pixels a digital number for their respective habitats. As classifications are stacked, the algorithm assigns pixels a new value based on change or no change. Special attention was given to ensure proper image registration and the overall accuracies of the classifications used in a post-classification change detection, as errors in both maps would affect the final output [22]. Change detections were performed for both East Ship and Sand Island, investigating 2007-2009, 2009-2010, 2010-2012 and 2007-2012 comparisons. 


\subsection{Elevation Analysis}

LIDAR data were post-processed, and Digital Terrain Models (DTM) of East Ship and Sand Island for 2012 were constructed (ArcGIS v10.1). Data were delivered by the vendor in Laser file exchange format (LAS) v1.2, following criteria set by the American Society for Photogrammetry and Remote Sensing [30]. LAS files were selected for East Ship and Sand by ensuring full island coverage based on a polygon tile scheme. Each island was represented by six LAS files. LAStools (University of North Carolina, Chapel Hill, NC, USA) software, was used to initially filter and remove noise by extracting values above $50 \mathrm{~m}$ in elevation. Bare earth point clouds were made by filtering all points not classified as 2 (bare earth). Water surface elevations were determined from partial reflection. Elevation rasters were then produced using the mean elevation of all bare earth points within a 1-m GSD; this generally consisted of 0-3 returns. A neighborhood raster calculator function then was used to interpolate elevation rasters to produce a smooth surface without data voids based on mean values within a $5 \times 5$ moving window. This method was chosen to mimic the collection of the NAIP imagery. A total of three iterations was performed to fill data voids in DTM rasters. Comparisons of field real-time network GPS observations with the derived elevation rasters confirmed the reported accuracy of the original LIDAR dataset [18]. Elevation rasters were then clipped using digitized shorelines from the 2012 ML mask. DTM rasters were referenced horizontally to NAD83 and vertically to NAVD88 and registered to the 2012 ML classifications. Habitat type classifications for 2012 were sampled on a pixel-by-pixel basis against the 2012 DTMs only.

\section{Results}

Due to spectral similarities between algal flat and beach dune herbland on East Ship, separate classifications were made for the spits and core sections of the island. These were mosaicked to produce a single seamless classification map for each year (Figure 2). Overall accuracies for individual classifications for East Ship and Sand (Figure 3) ranged from 82\%-95\% and 90\%-96\% respectively. Errors of commission and omission were generally limited to the misclassification of bare sand classed as beach dune herbland or algal flat classed as bare sand. Post-classification reports of total land area and habitat type coverage for East Ship Island indicated overall land area growth with an exception from 2009-2010, with fluctuations in habitat type coverage for all years (Table 2). Total land area on Sand Island also increased, except from 2010-2012, with fluctuations in individual habitat type coverage in all years (Table 2).

Change detections for East Ship and Sand Island were expressed as the total land area $\left(\mathrm{m}^{2}\right)$ that changed or remained stable within a given time period (Tables 3 and 4). Habitat transitions for both islands were similar for each period studied with the exception of algal flat on East Ship. The greatest habitat changes between 2007 and 2009 were to the beach dune herbland and algal flat classes on East Ship Island and the beach dune herbland and water classes on Sand. Algal flat (69\%) on East Ship transitioned to bare sand. However, algal flat was not present on Sand Island. Interestingly, both East Ship and Sand Island experienced a shift in habitat type from beach dune herbland to bare sand ( $87 \%$ and $45 \%$, respectively). The water class on Sand Island changed to bare sand, with small changes to the marsh shrubland and beach dune herbland class. Habitat transitions were much smaller on both islands from 2009-2010 with habitat shifts occurring in algal flat transitioning to bare sand on East Ship and water transitioning to marsh shrubland on Sand. From 2010-2012, both islands experienced changes similar to those in 2007-2009. On East Ship Island, algal flat and beach dune herbland habitat transitioned to bare sand ( $98 \%$ and $62 \%$, respectively). On Sand Island, bare sand (26\%) changed to sub-aqueous, beach dune herbland to marsh shrubland and bare sand $(19 \%$ and $18 \%$, respectively) and water (28\%) to marsh shrubland. Spanning the full temporal range of the study (2007-2012), East Ship Island's most stable habitats were marsh shrubland and water with transitions of nearly all of the algal flat (98\%) and beach dune herbland (74\%) to bare sand. Beach dune herbland on Sand transitioned mainly to marsh shrubland with smaller transitions of bare sand to beach dune herbland. Gains to bare sand from sub-aqueous occurred on both islands. Additionally, East Ship 
experienced a major reduction in its water class and transitioned primarily to bare sand and marsh shrubland, whereas water on Sand Island primarily transitioned to marsh shrubland.

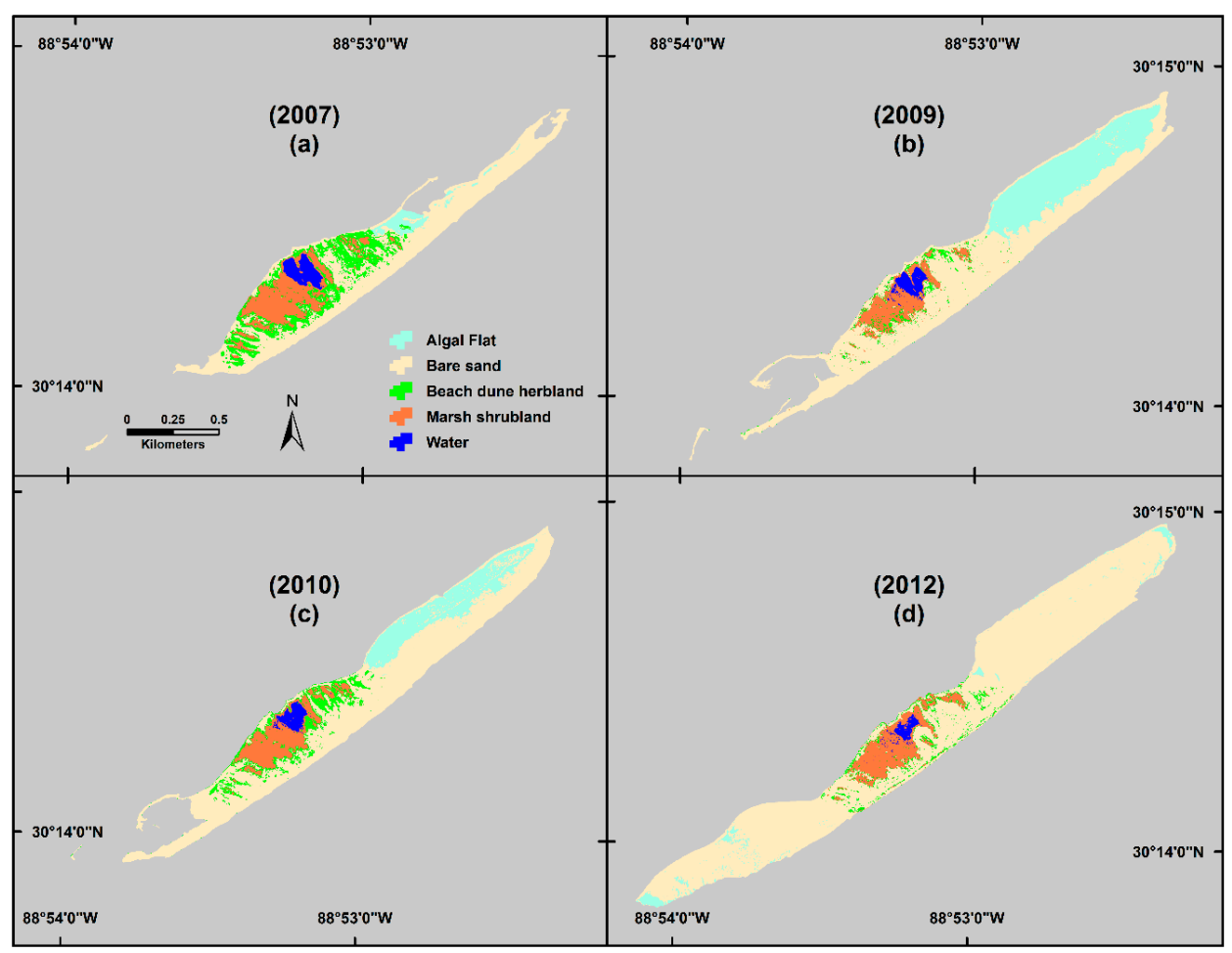

Figure 2. Maximum Likelihood classifications of East Ship Island for the years: (a) 2007; (b) 2009; (c) 2010; and (d) 2012.

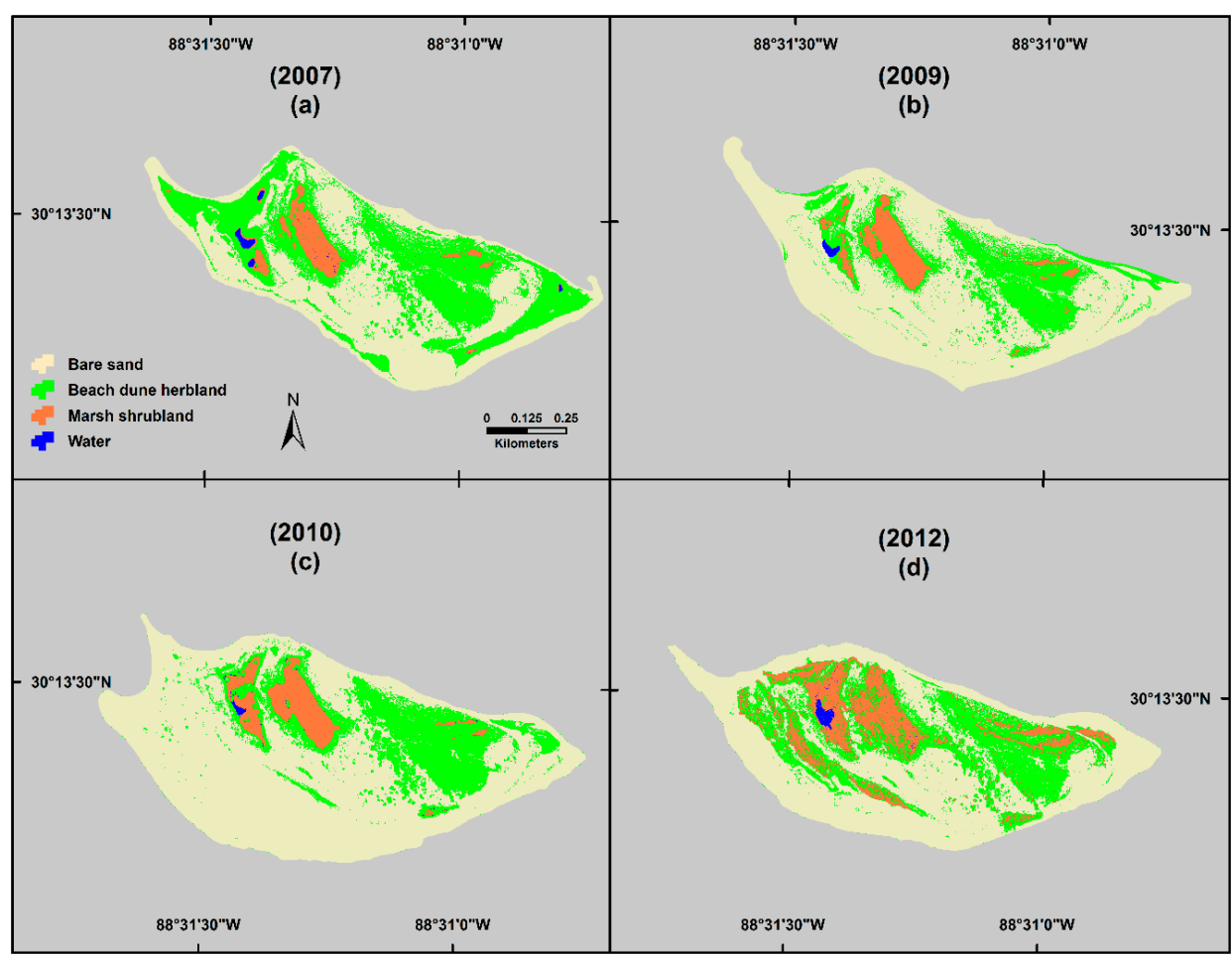

Figure 3. Maximum Likelihood classifications of Sand Island for the years: (a) 2007; (b) 2009; (c) 2010; and (d) 2012. 
Table 2. Total and relative land cover of East Ship and Sand habitat types in 2007, 2009, 2010 and 2012.

\begin{tabular}{ccccc}
\hline \multicolumn{5}{c}{ East Ship Island } \\
\hline \multicolumn{5}{c}{ Area $\left(\mathrm{m}^{2}\right)$ and relative $(\%$, in parentheses) land cover } \\
\hline Habitat type & 2007 & 2009 & 2010 & 2012 \\
Algal flat & $23,063(4)$ & $207,790(28)$ & $119,581(17)$ & $29,848(3)$ \\
Bare sand & $314,992(56)$ & $431,108(58)$ & $446,746(63)$ & $811,465(84)$ \\
Beach dune herbland & $106,415(19)$ & $19,778(3)$ & $55,453(8)$ & $26,615(3)$ \\
Marsh shrubland & $99,579(18)$ & $66,051(9)$ & $74,337(10)$ & $82,957(9)$ \\
Water & $22,602(4)$ & $17,323(2)$ & $15,846(2)$ & $9906(1)$ \\
Total land area & 566,651 & 742,050 & 711,963 & 960,791 \\
\hline \multicolumn{5}{c}{ Sand Island } \\
Habitat type & 2007 & 2009 & 2012 \\
Algal flat & - & - & - \\
Bare sand & $275,991(53)$ & $371,330(70)$ & $492,867(72)$ & $331,478(57)$ \\
Beach dune herbland & $210,967(41)$ & $121,200(23)$ & $150,237(22)$ & $158,613(27)$ \\
Marsh shrubland & $27,380(5)$ & $35,334(7)$ & $40,352(6)$ & $83,601(14)$ \\
Water & $2926(1)$ & $1458(0)$ & $1443(0)$ & $3154(1)$ \\
Total land area & 517,264 & 529,322 & 684,899 & 576,746 \\
\hline
\end{tabular}

Table 3. Change detection statistics for 2007-2009, 2009-2010, 2010-2012 and 2007-2012 habitat types on East Ship Island. Note: Hurricanes Gustav and Isaac made landfall on the Mississippi Coast on 1 September 2008 and 29 August 2012, respectively.

\begin{tabular}{|c|c|c|c|c|c|c|}
\hline \multicolumn{7}{|c|}{ Area $\left(\mathrm{m}^{2}\right)$ and Percent Change $(\%$, in Parentheses) } \\
\hline \multicolumn{7}{|c|}{2007} \\
\hline Sub-aqueous & Algal flat & Bare sand & Beach dune herbland & Marsh shrubland & Water & 2009 \\
\hline - & - & - & - & - & - & Unclassified \\
\hline $189,037(1)$ & $7256(31)$ & $11,416(4)$ & $81(0)$ & - & - & Algal flat \\
\hline $92,440(1)$ & $15,807(69)$ & $196,502(62)$ & $92,318(87)$ & $30,444(31)$ & 3597 (16) & Bare sand \\
\hline $763(0)$ & - & $2181(1)$ & $6803(6)$ & $8650(9)$ & $1381(6)$ & Beach dune herbland \\
\hline $291(0)$ & - & $864(0)$ & $5546(5)$ & $56,613(57)$ & 2737 (12) & Marsh shrubland \\
\hline - & - & - & $4(0)$ & 2968 (3) & $14,352(63)$ & Water \\
\hline $13,467,213(98)$ & - & $104,029(33)$ & $1663(2)$ & $904(1)$ & $535(2)$ & Sub-aqueous \\
\hline \multicolumn{7}{|c|}{2009} \\
\hline Sub-aqueous & Algal flat & Bare sand & Beach dune herbland & Marsh shrubland & Water & 2010 \\
\hline- & - & - & - & - & - & Unclassified \\
\hline $612(0)$ & $115,199(55)$ & $3770(1)$ & - & - & - & Algal flat \\
\hline $35,212(0)$ & $85,726(41)$ & $321,311(75)$ & 2639 (13) & $1552(2)$ & $306(2)$ & Bare sand \\
\hline $448(0)$ & - & $42,904(10)$ & $7268(37)$ & $4584(7)$ & $249(1)$ & Beach dune herbland \\
\hline- & - & 5449 (1) & 8649 (44) & $57,028(86)$ & 3211 (19) & Marsh shrubland \\
\hline - & - & $12(0)$ & $48(0)$ & $2229(3)$ & $13,557(78)$ & Water \\
\hline $13,538,073(100)$ & $6865(3)$ & $57,662(13)$ & $1174(6)$ & $658(1)$ & - & Sub-aqueous \\
\hline \multicolumn{7}{|c|}{2010} \\
\hline Sub-aqueous & Algal flat & Bare sand & Beach dune herbland & Marsh shrubland & Water & 2012 \\
\hline- & - & - & - & - & - & Unclassified \\
\hline $23,543(0)$ & $1925(2)$ & $4378(1)$ & $2(0)$ & - & - & Algal flat \\
\hline $291,399(2)$ & $117,656(98)$ & $359,228(80)$ & $34,325(62)$ & $8260(11)$ & $597(4)$ & Bare sand \\
\hline $537(0)$ & - & $14,173(3)$ & $8507(15)$ & $3280(4)$ & $118(1)$ & Beach dune herbland \\
\hline $259(0)$ & - & $4156(1)$ & $10,641(19)$ & $61,171(82)$ & $6730(42)$ & Marsh shrubland \\
\hline - & - & - & $9(0)$ & $1496(2)$ & $8401(53)$ & Water \\
\hline $13,288,694(98)$ & - & $64,811(15)$ & $1969(4)$ & $130(0)$ & - & Sub-aqueous \\
\hline \multicolumn{7}{|c|}{2007} \\
\hline Sub-aqueous & Algal flat & Bare sand & Beach dune herbland & Marsh shrubland & Water & 2012 \\
\hline- & - & - & - & - & - & Unclassified \\
\hline $28,345(0)$ & $389(2)$ & $1105(0)$ & $9(0)$ & - & - & Algal flat \\
\hline $534,920(4)$ & $22,602(98)$ & $144,585(46)$ & $78,726(74)$ & $24,971(25)$ & $5661(25)$ & Bare sand \\
\hline $690(0)$ & $21(0)$ & $7878(3)$ & $10,194(10)$ & $6913(7)$ & $919(4)$ & Beach dune herbland \\
\hline $231(0)$ & - & $3305(1)$ & $10,310(10)$ & $63,155(63)$ & $5956(26)$ & Marsh shrubland \\
\hline - & - & -2 & $69(0)$ & $1596(2)$ & $8241(36)$ & Water \\
\hline $13,185,558(96)$ & $51(0)$ & $158,119(50)$ & 7107 (7) & 2994 (3) & $1825(8)$ & Sub-aqueous \\
\hline
\end{tabular}


Table 4. Change detection statistics for 2007-2009, 2009-2010, 2010-2012 and 2007-2012 habitat types on Sand Island. Note: Hurricanes Gustav and Isaac made landfall on the Mississippi Coast on 1 September 2008 and 29 August 2012, respectively.

\begin{tabular}{|c|c|c|c|c|c|}
\hline \multicolumn{6}{|c|}{ Area $\left(\mathrm{m}^{2}\right)$ and Percent Change $(\%$, in Parentheses) } \\
\hline \multicolumn{6}{|c|}{2007} \\
\hline Sub-aqueous & Bare sand & Beach dune herbland & Marsh shrubland & Water & 2009 \\
\hline- & - & - & - & - & Unclassified \\
\hline $61,381(2)$ & $212,612(77)$ & $94,988(45)$ & $1592(6)$ & $757(26)$ & Bare sand \\
\hline $5717(0)$ & $15,525(6)$ & $97,003(46)$ & $2714(10)$ & $242(8)$ & Beach dune herbland \\
\hline- & $282(0)$ & $11,490(5)$ & $23,012(84)$ & $549(19)$ & Marsh shrubland \\
\hline - & - & $21(0)$ & $59(0)$ & $1378(40)$ & Water \\
\hline $3,467,942(95)$ & $47,572(17)$ & $7465(4)$ & $3(3)$ & - & Sub-aqueous \\
\hline \multicolumn{6}{|c|}{2009} \\
\hline Sub-aqueous & Bare sand & Beach dune herbland & Marsh shrubland & Water & 2010 \\
\hline- & - & - & - & - & Unclassified \\
\hline $171,951(5)$ & $307,213(83)$ & $13,603(11)$ & $100(0)$ & - & Bare sand \\
\hline $1405(0)$ & $46,839(13)$ & $97,014(80)$ & 4729 (13) & $250(17)$ & Beach dune herbland \\
\hline- & $904(0)$ & $8622(7)$ & $30,439(80)$ & $388(27)$ & Marsh shrubland \\
\hline- & $90(0)$ & $467(0)$ & $66(0)$ & $820(56)$ & Water \\
\hline $3,349,626(95)$ & $16,284(4)$ & $1494(1)$ & - & - & Sub-aqueous \\
\hline \multicolumn{6}{|c|}{2010} \\
\hline Sub-aqueous & Bare sand & Beach dune herbland & Marsh shrubland & Water & 2012 \\
\hline- & - & - & - & - & Unclassified \\
\hline $22,820(1)$ & $281,086(57)$ & $27,464(18)$ & $107(0)$ & - & Bare sand \\
\hline $73(0)$ & $60,126(12)$ & $92,196(61)$ & 6061 (15) & $157(11)$ & Beach dune herbland \\
\hline $24(0)$ & $21,516(4)$ & $29,269(19)$ & $32,384(80)$ & $408(28)$ & Marsh shrubland \\
\hline- & - & $477(0)$ & $1800(4)$ & $878(61)$ & Water \\
\hline $3,344,488(99)$ & $130,139(26)$ & $831(1)$ & - & - & Sub-aqueous \\
\hline \multicolumn{6}{|c|}{2007} \\
\hline Sub-aqueous & Bare sand & Beach dune herbland & Marsh shrubland & Water & 2012 \\
\hline- & - & - & - & - & Unclassified \\
\hline $125,401(4)$ & $153,262(56)$ & $51,894(25)$ & $730(3)$ & $191(7)$ & Bare sand \\
\hline $17,852(1)$ & $41,571(15)$ & $94,075(45)$ & 4960 (18) & $155(5)$ & Beach dune herbland \\
\hline $7126(0)$ & $17,552(6)$ & $37,172(18)$ & $20,664(75)$ & $1087(37)$ & Marsh shrubland \\
\hline- & - & 1127 (1) & $558(2)$ & $1469(50)$ & Water \\
\hline $3,384,661(96)$ & $63,606(23)$ & $26,699(13)$ & $468(2)$ & $24(1)$ & Sub-aqueous \\
\hline
\end{tabular}

The 2012 DTMs for East Ship and Sand indicated a maximum elevation of $4.50 \mathrm{~m}$ and $9.34 \mathrm{~m}$ and a minimum elevation of $-0.50 \mathrm{~m}$ and $-0.28 \mathrm{~m}$ NAVD88, respectively (Table 5$)$. The presence of several overwash lobes, overwash channels, elongated fore and back dunes and a pond could be noted on East Ship Island. Whereas on Sand, only the presence of elongated fore and back dunes and a pond could be delineated (Figures 4 and 5). Minimum elevations for common habitat types were similar for both islands with between island differences of $22 \mathrm{~cm}$ for bare sand, $6 \mathrm{~cm}$ for beach dune herbland, $6 \mathrm{~cm}$ for marsh shrubland and $31 \mathrm{~cm}$ for water. Maximum elevations of common habitats were considerably higher on Sand Island, with the exception of water. Although mean elevations for common habitats were slightly higher on Sand Island than East Ship, the differences between them were approximately $1 \mathrm{~m}$ or less.

Table 5. Minimum, maximum and mean elevations of habitat types on East Ship and Sand.

\begin{tabular}{cccc}
\hline \multicolumn{4}{c}{ East Ship Island } \\
\hline \multicolumn{4}{c}{ Elevation (m NAVD88) } \\
\hline Habitat type & Minimum & Maximum & Mean \\
Algal flat & -0.05 & 1.48 & 0.61 \\
Bare sand & -0.06 & 4.50 & 0.90 \\
Beach dune herbland & 0.11 & 3.62 & 1.41 \\
Marsh shrubland & 0.13 & 3.62 & 1.39 \\
Water & 0.14 & 2.82 & 0.54 \\
\hline \multicolumn{4}{c}{} \\
\hline Habitat type & Sand Island & \\
Algal flat & Minimum & Maximum & Mean \\
Bare sand & - & - & - \\
Beach dune herbland & -0.28 & 8.95 & 1.98 \\
Marsh shrubland & 0.05 & 9.34 & 2.37 \\
Water & 0.07 & 9.17 & 1.23 \\
& 0.45 & 1.80 & 0.75 \\
\hline
\end{tabular}




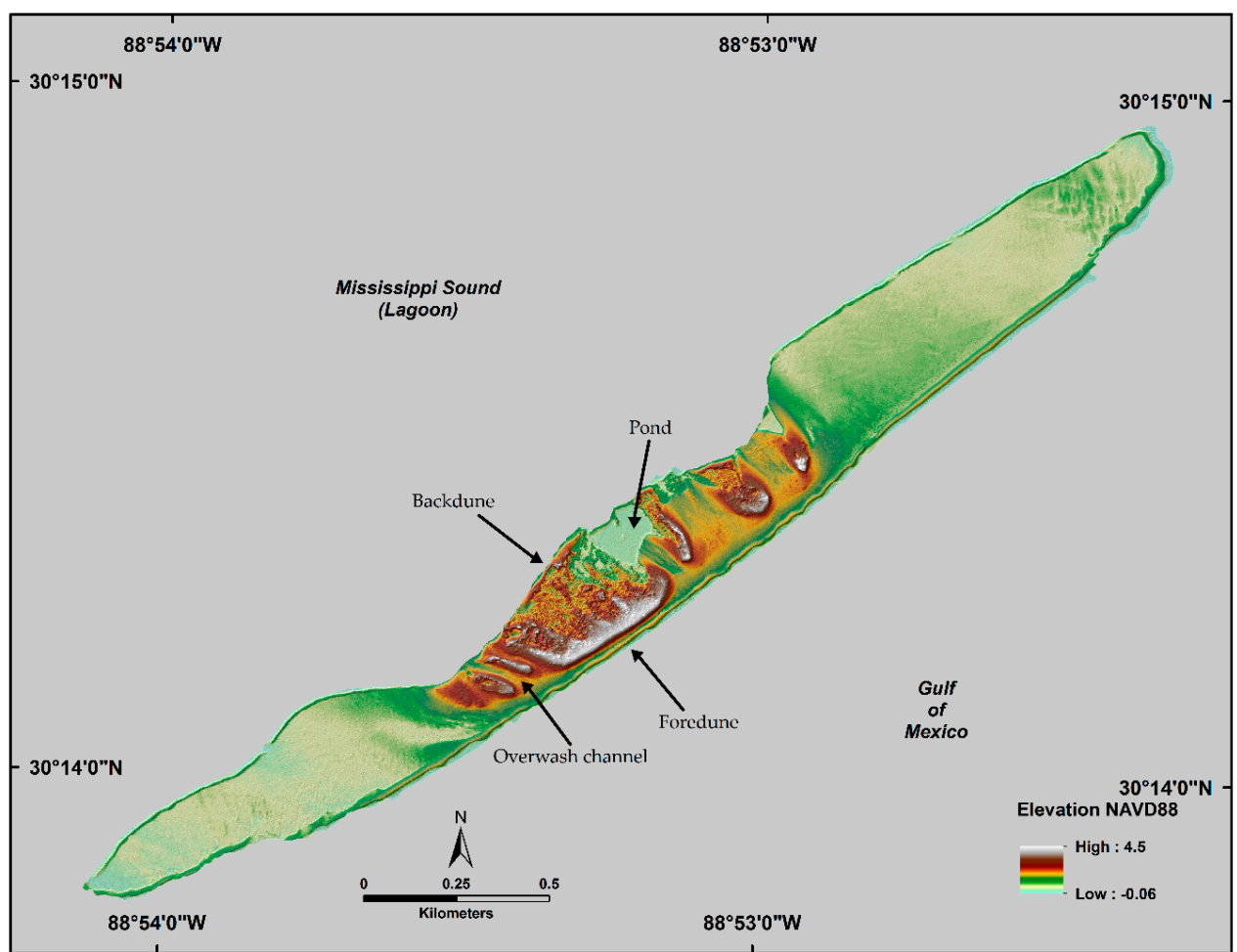

Figure 4. DTM of East Ship Island (2012) delineating the island's minimum and maximum elevations along with geomorphic features.

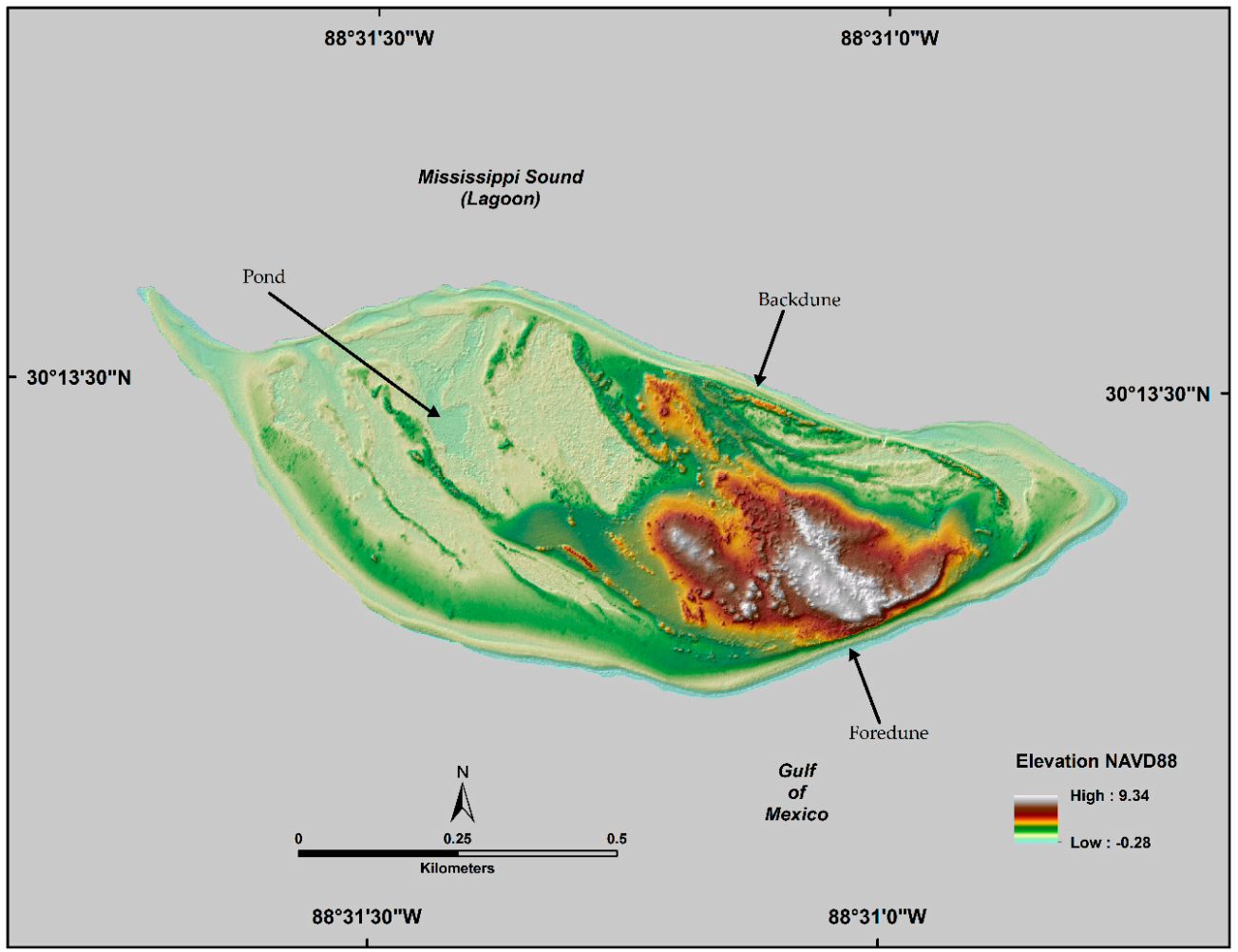

Figure 5. DTM of Sand Island (2012) delineating the island's minimum and maximum elevations along with geomorphic features. 


\section{Discussion}

On islands, bare sand provides the parent material needed for pioneering grass species that eventually are replaced by shrub and woodland habitats via succession [31]. However, bare sand is very unstable and may be found among a variety of habitat types. Substrate elevation and elevational differences, which might be considered trivial in other ecosystems, largely control vegetation composition on barrier islands [3]. This study compared two islands within the same barrier chain, one man-made and one occurring naturally, and examined the changes in geomorphic and biological features over a seven-year time period. Additionally, ranges in the elevation of the corresponding habitat types were compared using the 2012 habitat classification and a 2012 Digital Terrain Model (DTM) constructed from LIDAR. After investigating the aforementioned subject matter, both islands were found to exhibit remarkably similar geomorphic characteristics and vegetation composition. With the exception of algal flat found on East Ship Island, both islands contained the same habitat types and were found to exist at comparable ranges in elevation (Figure 6). For example, on both islands, plant species, such as sea oat, beach morning glory and gulf bluestem, were indicative of the beach dune herbland habitat type, and salt meadow, smooth cordgrass, marsh elder and wax myrtle were symbolic of the marsh shrubland habitat type. Additionally, changes in vegetation coverage and geomorphology were similar over the period of investigation. For example, bare sand transitioned mainly to and from algal flat and beach dune herbland through overwash and aeolian burial of vegetation. Identifying an ecosystems' climax species allows the definition of successional stage [32]. Sand Island, because it is much younger than East Ship Island, lacks woody vegetation, such as slash pine (Pinus elliottii var. elliottii Engelm) and sand live oak that sparsely inhabit East Ship Island. Although these two species constitute the climax community vegetation on East Ship Island, their coverage is not sufficient in differentiating them from the shrub species that make up the marsh shrubland habitat type. The climax community species found on Sand Island are wax myrtle (Morella cerifera) and smaller shrubs, such as marsh elder (Iva frutescens).

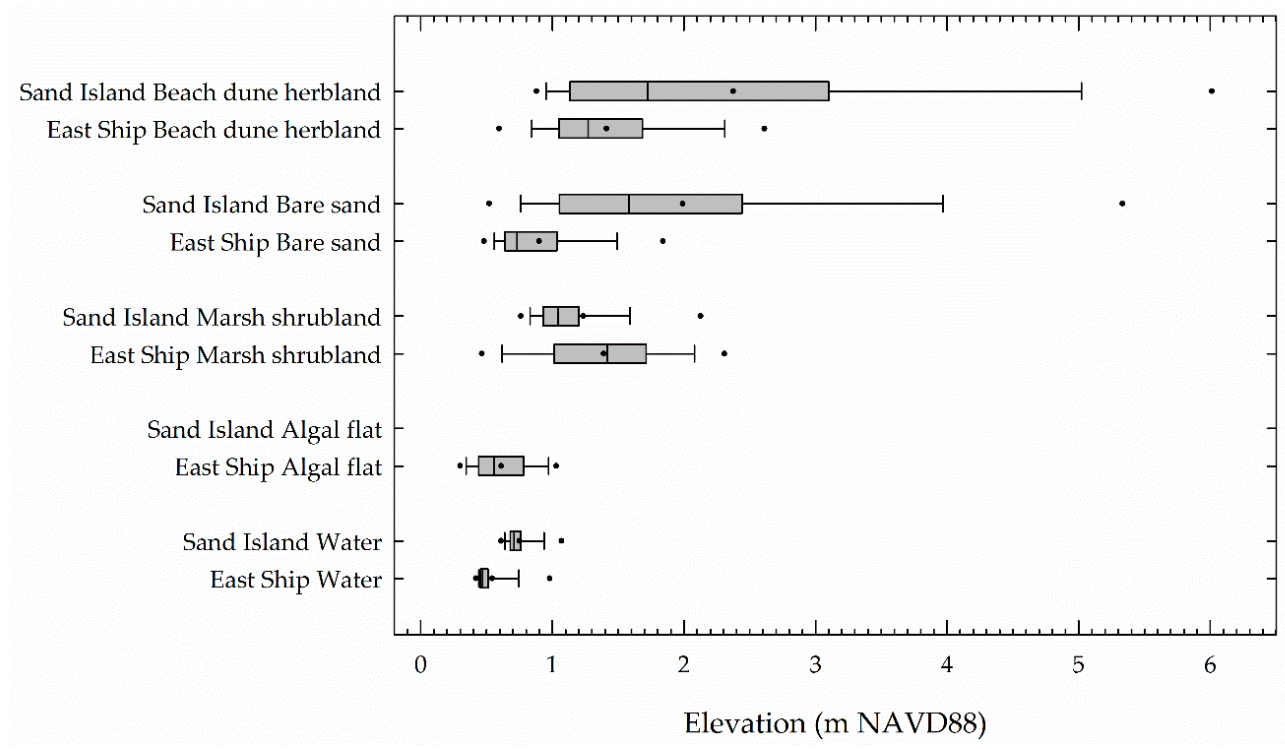

Figure 6. Box and whisker plot showing the relationship between habitat (2012 ML classification) and elevation (2012 DTM) on both islands. The line and dot within each box represent the median and mean, respectively. Box widths represent the middle $50 \%$ of the data about the median; $75 \%$ of the data lie between the horizontal bars ("whiskers"). The dots outside the horizontal bars represent the extreme minimum and maximum $5 \%$ and $10 \%$ of the data.

Absent on Sand Island, the algal flat habitat on East Ship was expanded by Hurricane Gustav. Overwash from Gustav's shore normal tidal surge in 2008 aided in the creation of a large intertidal 
zone, extending from the island's core down the entire length of the northeast spit (Figure 7). Due to the low mean elevation of beach dune herbland, major transitions occurred in the habitat, with as much as 90\% loss in its total land area from 2007-2009. Approximately half of the beach dune herbland habitat type on Sand Island transitioned to bare sand following Gustav, due to run-up overwash on fore and back dunes. The storm also caused a foredune blowout responsible for the partial filling of East Ship's pond. While losses did occur in the marsh shrubland habitat type on East Ship Island, they were not as profound as they were in other habitat types. This was likely due to protection from its fore and back dunes. The impact of Gustav on East Ship added total land area, while reducing vegetated habitat coverage. The effects on Sand Island were limited mainly to the lower-elevation beach dune herbland (Figure 3a,b). Some spit reworking and land growth on the island's southeast flank were visually identifiable in the NAIP imagery.

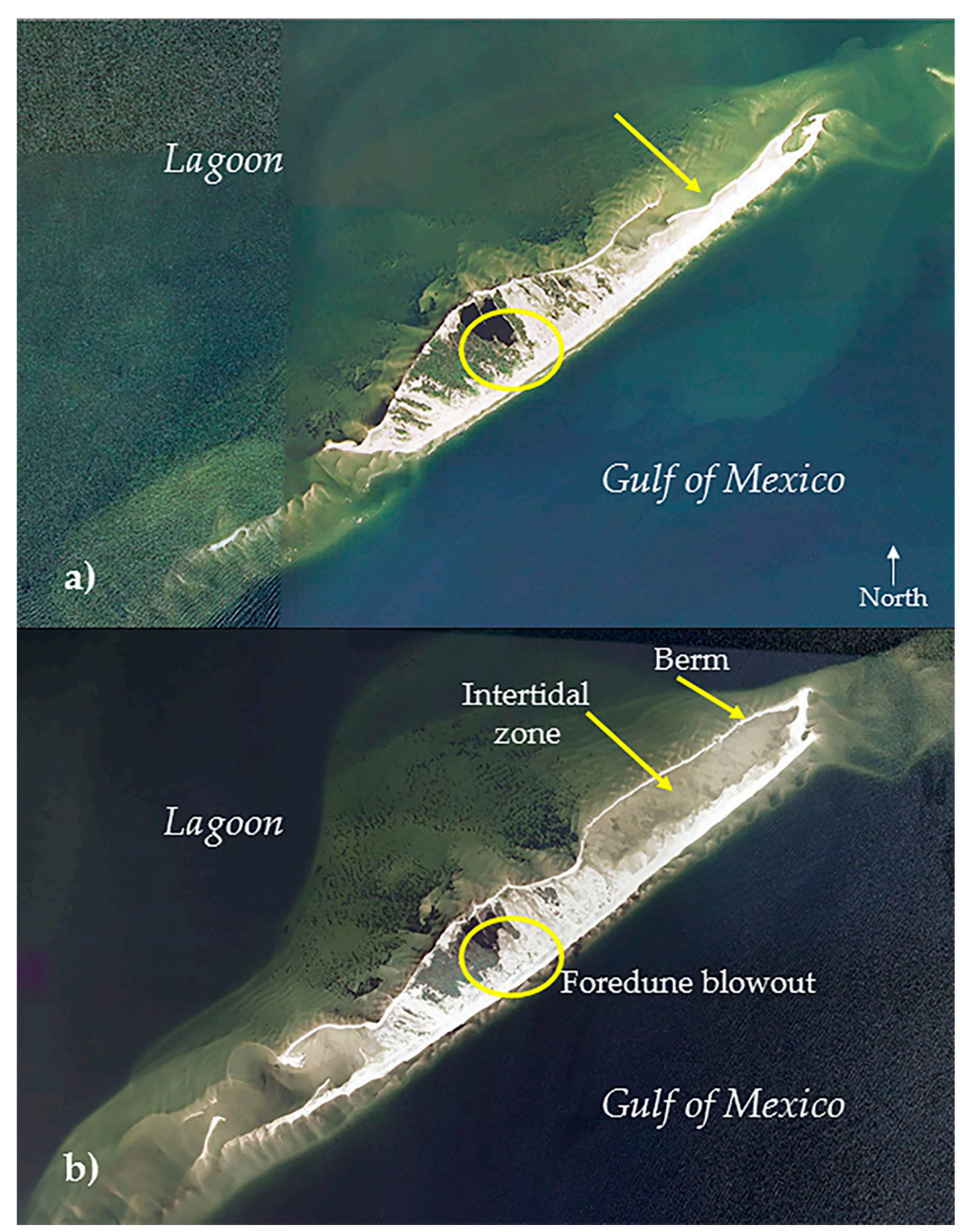

Figure 7. NAIP imagery of East Ship Island from (a) 2007 and (b) 2009 showing geographic features before and after Hurricane Gustav in 2008. The circled area represents the partial filling of East Ship's pond due to a foredune blowout. Arrows show an intertidal zone and berm construction. 
Smaller changes were seen from 2009-2010 on both islands. The building of a small berm post-Gustav on the lagoonal side of East Ship's major intertidal zone allowed sediment deposition to reduce the algal flat considerably (Figure $2 b, c$ and Figure 7 ). Reestablishment of beach dune herbland took place after Gustav between 2009 and 2010 (Figure 2b,c). On both islands, approximately 4 ha of bare sand transitioned to beach dune herbland. Marsh shrubland also increased on East Ship, with small transitions from beach dune herbland, indicating succession of beach grasses to meadow grasses. Reports on dredging activities in the Mississippi Sound by the United States Army Corps of Engineers (USACE) are not easily accessible and, in some cases, are not made public [33]. Nevertheless, a major addition of bare sand took place on Sand Island between 2009 and 2010, likely the result of artificial deposition from dredge material (Figure $3 b, c$ and Figure 8).

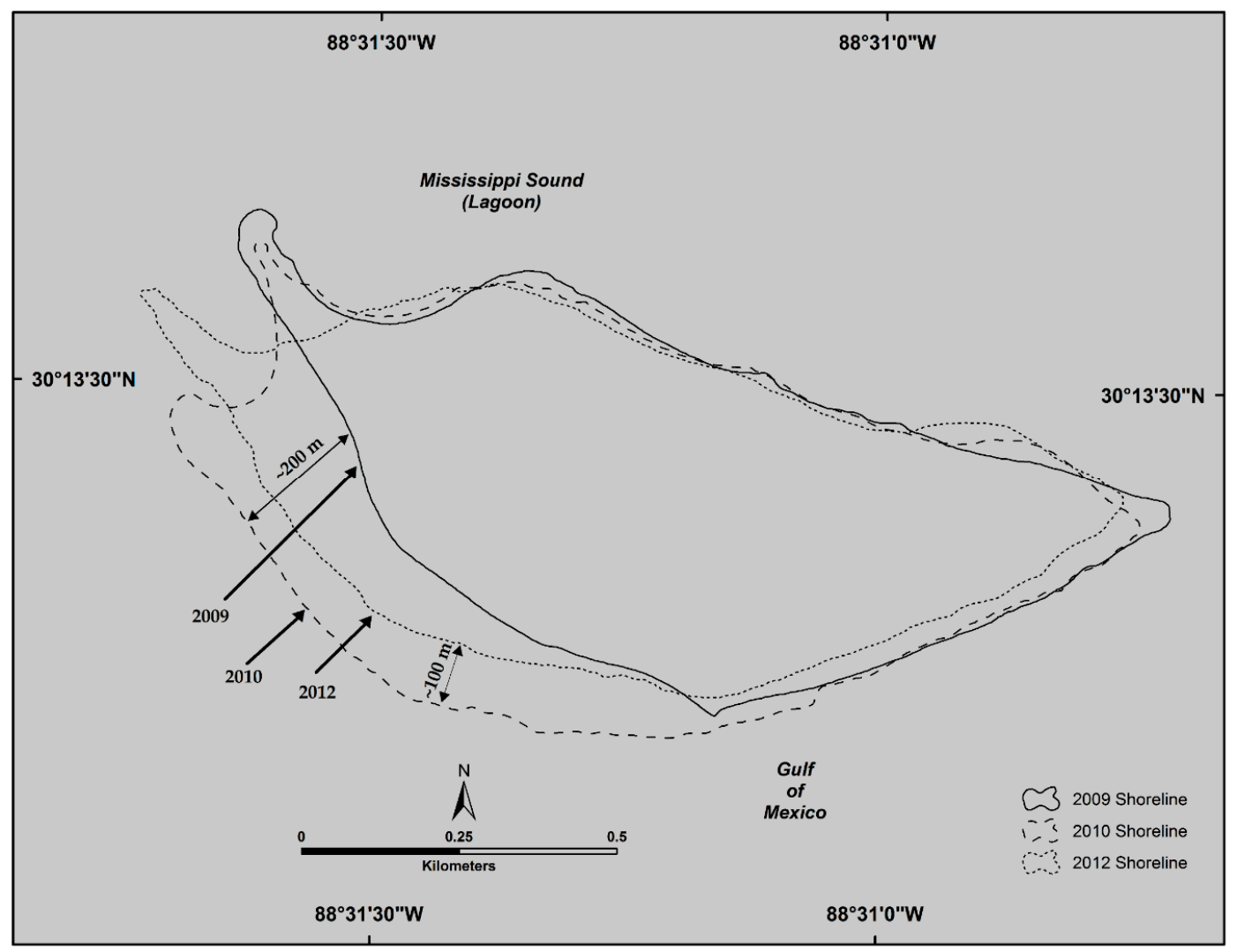

Figure 8. Map showing Sand Island shoreline change from deposition of dredge material (2009-2010) and Hurricane Isaac (2012). Shorelines are represented by a solid line for 2009 (pre-deposition), large dashed line for 2010 (post-deposition, pre-Isaac) and a small dashed line for 2012 (post-Isaac).

Major changes on both islands from 2010-2012 are attributed to the impact of Hurricane Isaac. The slower forward speed of Isaac led to prolonged periods of storm tide run-up overwash and high southeast wind and wave fetch, shaping both islands geomorphically and ecologically [34]. Approximately 23 ha of bare sand were added to East Ship's southeast spit, completely reshaping the island and skipping the algal flat successional phase (Figure 2c,d). Additionally, the majority of algal flat on the northeast spit transitioned to bare sand through sand overwash and burial (Figure 2c,d). Presumably, the higher mean elevation of beach dune herbland on Sand allowed for it to remain relatively stable during Isaac. This was not the case on East Ship, as nearly all beach dune herbland reestablishment post-Gustav was eliminated by Isaac (Figure 2c,d). It is postulated that wind, wave and surge forces were not shore-normal on Sand as they were for East Ship during Isaac, resulting in approximately 11 ha of land loss on the island's southwest flank (Figure 8). Average water depths of $3 \mathrm{~m}$ flank Sand Island to the south and southwest, dropping steeply to about $5 \mathrm{~m}-6 \mathrm{~m}$ to the west 
and northwest of the island [35]. Sediment eroded from the island was most likely lost due to the sharp increase in depth. Depths between East and West Ship average $1.5 \mathrm{~m}$ and are gently sloping [36]. Further, sediment transport continues between West and East Ship Islands eroded tidal inlet via littoral drift. East Ship's land growth in 2012 could have been affected by the relatively shallow depths, allowing for sediment accretion [37].

In evaluating the similarities and differences between habitats and their respective elevations on both islands, it was noted that the range of water habitat on East Ship is larger and exists at lower elevations than water on Sand Island. This is presumably due to East Ship's pond being periodically tidally influenced, whereas Sand Island's pond is not. Although algal flat exists on East Ship and not on Sand Island, the habitat spans the entire range of elevation that the water habitat occupies on both islands. This is a function of a low elevation gradient and frequent tidal inundation found on the low elevated spits of East Ship Island. Sand Island lacks these particular geographic features. Interestingly, although Sand Island has a higher overall elevation by approximately $4.8 \mathrm{~m}$, the majority of its climax community species, which fall under the marsh shrubland habitat, exists at a lower range of elevation than the comparable community and habitat on East Ship. Currently, we attribute the higher range of elevation in marsh shrubland on East Ship to the differences between elevation gradients between the two islands. However, this subject warrants its own study. Finally, the ranges and overall elevation of bare sand and beach dune herbland were greater on Sand Island (Figure 6). The high between-island variability in elevations for these habitats is a function of Sand Island being created through artificial deposition of dredge material.

\section{Conclusions}

This study compared short-term (less than one decade) change in habitat type coverage with respective elevation, geomorphic features and total land area between naturally-formed East Ship Island and man-made Sand Island. Habitat types and species composition were the same on both islands with the exception of algal flat existing on the lower elevated spits of East Ship. DTMs showed very similar geomorphic characteristics on both islands, such as elongated fore and back dunes and ponds. However, relict dunes, which were indicative of sand live oak, were found only on East Ship. These biogeographic features were absent on the much younger Sand Island. While Sand Island has a higher overall mean elevation, common habitat types were found to inhabit like ranges of elevation, with between-island differences of about $1 \mathrm{~m}$ or less. Change detection analyses showed that these two islands are also succeeding similarly, with dominant shifts occurring to, and from, bare sand to beach dune herbland habitat types. This was evident after Hurricane Gustav, in which beach dune herbland was buried by sand and then quickly reestablished on both islands. Given the two storm impacts within the study period, the marsh shrubland habitat type was the most stable. On East Ship, Hurricanes Gustav and Isaac could be considered beneficial rather than detrimental because both storms added land area. Conversely, land area on Sand Island was lost likely the result of the interaction among island orientation, angle of wave approach and bathymetric slope during storm impacts. Previous long-term ecological and geomorphic investigations on the MS barrier islands have accredited change to subsidence and sea-level rise, sediment starvation, storm impacts and a warming climate. However, during this investigation, it was found that major vegetation and geomorphic change was attributed mostly to the impacts of Hurricanes Gustav and Isaac. While it is fairly common to attribute short-term change on barrier islands to tropical events, these two islands in particular responded similarly with respect to vegetation loss and reestablishment. Although they responded alike in terms of vegetation, this was not the case with geomorphic change. Interestingly, Sand Island behaved like a natural system when compared to East Ship Island. For example, both islands have a central core, which remained relatively stable during the time period studied. Additionally, the presence of Sand Island's stable fresh water pond coupled with freshwater-dependent vegetation further exhibits island stability, response and behavior in a natural system. In the brief time Sand Island has evolved, it appears to have responded to the natural biological and geomorphic drivers of change 
in much of the same ways as East Ship Island. Although vastly different in age, these two islands show remarkable commonalities among the traits investigated. In comparison to East Ship, Sand Island exhibits key characteristics of a natural barrier island in terms of its vegetated habitats, geomorphic features and response to storm impacts within the time period investigated. Although future studies are needed, this presents an interesting quandary that must be considered when determining dredge material borrow and placement sites. Sand Island has become a viable location for the growth and stability of flora and fauna mirroring the natural East Ship Island in many ways. In consideration of the future of the MS barrier island chain, Sand Island offers ecological and economic value to which barrier island protection and restoration may be compared.

Acknowledgments: This study was supported by NOAA and was conducted under a research permit provided by the U.S. National Park Service, Gulf Islands National Seashore (GUIS). The authors would like to thank GUIS for providing the permit and additional historical background information. Thanks to David Mooneyhan, Alan Criss, Chris Brown and Les Graham of the University of Southern Mississippi, Gulf Coast Geospatial Center, for technical support and the USDA for providing the NAIP imagery.

Author Contributions: Carlton Anderson and Gregory Carter conceived the idea for and designed the research. All authors collected, processed and analyzed the data. All authors prepped, wrote and edited the manuscript.

Conflicts of Interest: The authors declare no conflict of interest.

\begin{tabular}{|c|c|}
\hline MS & Mississippi \\
\hline NPS & National Park Service \\
\hline GUIS & Gulf Islands National Seashore \\
\hline NAVD88 & North American Vertical Datum 1988 \\
\hline USDA & United States Department of Agriculture \\
\hline NAIP & National Agricultural Imagery Program \\
\hline GCP & Ground Control Point \\
\hline LIDAR & Light Detection and Ranging \\
\hline BV & Brightness Value \\
\hline NAD & North American Datum \\
\hline UTM & Universal Transverse Mercator \\
\hline ROI & Region of Interest \\
\hline ML & Maximum Likelihood \\
\hline GPS & Global Positioning System \\
\hline DTM & Digital Terrain Model \\
\hline LAS & Laser file exchange \\
\hline $\begin{array}{l}\text { USACE } \\
\text { ha }\end{array}$ & $\begin{array}{l}\text { United States Army Corps of Engineers } \\
\text { hectares }\end{array}$ \\
\hline
\end{tabular}

\section{References}

1. Cooper, A.B. Fetch-limited barrier islands: Overlooked coastal landforms. Geol. Soc. Am. 2007, 17, 1-9. [CrossRef]

2. Pilkey, O.H.; Cooper, J.A.; Lewis, D.A. Global distribution and geomorphology of fetch-limited barrier island. J. Coast. Res. 2009, 25, 819-837. [CrossRef]

3. Lucas, K.L.; Carter, G.A. Decadal changes in habitat-type coverage on Horn Island, Mississippi, USA. J. Coast. Res. 2010, 26, 1142-1148. [CrossRef]

4. Stauble, D.K. Barrier Islands-Dynamic Coastal Landforms Requiring Complex Management Decisions, a Symposium Introduction and Overview, 1st ed.; American Society of Civil Engineers: New York, NY, USA, 1989.

5. Aguilar, C.; Zinnert, J.C.; Polo, M.J.; Young, D.R. NDVI as an indicator for changes in water availability to woody vegetation. Ecol. Indic. 2012, 23, 290-300. [CrossRef]

6. Ruppel, C.; Schultz, G.; Kruse, S. Anomalous fresh water lens morphology on a strip barrier island. Ground Water 2000, 38, 872-881. [CrossRef]

7. Schneider, J.C.; Kruse, S.E. A comparison of controls on freshwater lens morphology of small carbonate and siliciclastic islands: Examples from barrier islands in Florida, USA. J. Hydrol. 2003, 284, 253-269. [CrossRef]

8. Ehrenfeld, J.G. Dynamics and processes of barrier island vegetation. Rev. Aquat. Sci. 1990, 2, 437-480. 
9. Oosting, H.J. Tolerance to salt spray of plant of coastal dunes. Ecology 1954, 26, 85-89. [CrossRef]

10. Jeter, G.W.; Carter, G.A. Habitat change on Horn Island, Mississippi, 1940-2010, determined from textural features panchromatic vertical aerial imagery. Geocarto Int. 2015. [CrossRef]

11. Otvos, E.G.; Carter, G.A. Hurricane degradation-barrier development cycles, northeastern Gulf of Mexico: Landform evolution and island chain history. J. Coast. Res. 2008, 24, 463-478. [CrossRef]

12. Otvos, E.G. Barrier island formation through nearshore aggradation-Stratigraphic and field evidence. Mar. Geol. 1981, 43, 195-243. [CrossRef]

13. Morton, R.A. Historical changes in the Mississippi-Alabama barrier islands and the roles of extreme storms, sea level and human activities. J. Coast. Res. 2008, 24, 1587-1600. [CrossRef]

14. Otvos, E.G.; Giardino, M.J. Interlinked barrier chain and delta lobe development, northern Gulf of Mexico. Sediment. Geol. 2004, 169, 47-72. [CrossRef]

15. Schmid, K. East Ship Island Evolution, Morphology, and Hurricane Response-1994 to 2001; Open-File Report; Mississippi Department of Environmental Quality: Jackson, MS, USA, 2003; Volume 134, p. 7.

16. Byrnes, M.R.; Rosati, J.D.; Griffee, S.F.; Berlinghoff, J. Historical sediment transport pathways and quantities for determining an operational sediment budget: Mississippi sound barrier islands. J. Coast. Res. 2013, 63, 166-183. [CrossRef]

17. Otvos, E.G.; Carter, G.A. Regressive and transgressive barrier islands on the North-Central Gulf Coast-Contrast in evolution, sediment delivery, and island vulnerability. Geomorphology 2013, 198, 1-19. [CrossRef]

18. Funderburk, W.R.; Carter, G.A.; Anderson, C.P. Evaluating the influence of elevation and impact of Hurricane Katrina on radial growth in slash pine (Pinus elliottii var. elliottii Engelm) on Cat Island, Mississippi, USA. J. Coast. Res. 2016, 32, 483-489. [CrossRef]

19. Berg, R. Tropical Cyclone Report Hurricane Isaac; Paper AL092012; National Hurricane Center: Miami, FL, USA, 2013.

20. Beven, J.L.; Kimberlain, T.B. Tropical Cyclone Report Hurricane Gustav; Paper AL072008; National Hurricane Center: Miami, FL, USA, 2009.

21. United States Department of Agriculture. Farm Service Agency and Aerial Photography Field Office. USDA-FSA-APFO Digital Ortho Mosaic; United States Department of Agriculture Publication: Salt Lake City, UT, USA, 2012.

22. Jensen, J.R. Introductory Digital Image Processing: A Remote Sensing Perspective; Prentice-Hall: Upper Saddle River, NJ, USA, 2005.

23. Carter, G.A.; Anderson, C.P.; Funderburk, W.R.; Jeter, G.W.; Otvos, E.G.; Lucas, K.L.; Hopper, N. Vegetation cover and relationships of habitat-type with elevation on the Mississippi-Alabama barrier islands in the initial six years after Hurricane Katrina. In Proceedings of the American Geophysical Union (AGU) Fall Meeting, San Francisco, CA, USA, 14-18 December 2015; Abstract Number 81138.

24. Lucas, K.L.; Carter, G.A. The use of hyperspectral remote sensing to assess vascular plant species richness on Horn Island, Mississippi. Remote Sens. Environ. 2008, 112, 3908-3915. [CrossRef]

25. Mississippi Natural Heritage Program. Ecological Communities of Mississippi, Museum of Natural Science; Mississippi Department of Wildlife, Fisheries, and Parks: Jackson, MS, USA, 2006.

26. Peneva, W.T.; Griffith, J.; Carter, G.A. Seagrass mapping in the Northern Gulf of Mexico using airborne hyperspectral imagery: A comparison of classification methods. J. Coast. Res. 2008, 24, 850-856. [CrossRef]

27. Boak, E.H.; Turner, I.L. Shoreline definition and detection: A review. J. Coast. Res. 2005, 21, 688-703. [CrossRef]

28. Boschetti, L.; Flasse, S.P.; Brivio, P.A. Analysis of the conflict between omission and commission in low spatial resolution dichotomic thematic products: The pareto boundary. Remote Sens. Envrion. 2004, 91, 280-292. [CrossRef]

29. Singh, A. Digital change detection techniques using remotley-sensed data. Int. J. Remote Sens. 1989, 10, 989-1003. [CrossRef]

30. American Society for Photogrammetery and Remote Sensing. LAS Specification Version 1.2; American Society for Photogrammetry and Remote Sensing Publication: Bethesda, MD, USA, 2008; pp. 1-13.

31. Maun, A.M. The Biology of Coastal Sand Dunes; Oxford University Press: New York, NY, USA, 2009.

32. MacDonald, G.M. Biogeography: Space, Time, and Life, 1st ed.; John Wiley \& Sons, Inc.: New York, NY, USA, 2003. 
33. Parson, L.E.; Swafford, R. Beneficial use of sediments from dredging activities in the Gulf of Mexico. J. Coast. Res. 2012, 60, 45-50. [CrossRef]

34. Guy, K.K.; Stockdon, H.F.; Plant, N.G.; Doran, K.S.; Morgan, K.L.M. Hurricane Isaac: Observations and Analysis of Coastal Change; Open-File Report, 1270; United States Geological Survey: Reston, VA, USA, 2013.

35. NOAA. Pascagoula Harbor Chart 11375. Available online: http://www.charts.noaa.gov/OnLineViewer/ 11375.shtml (accessed on 15 February 2015).

36. NOAA. Intracoastal Waterway Dog Keys Pass to Waveland Small Craft Route IWW Route Chart. Available online: http:/ / www.charts.noaa.gov/OnLineViewer/11372.shtml (accessed on 15 February 2015).

37. Cipriani, L.E.; Stone, G.W. Net longshore sediment transport and textural changes in beach sediments along the Southwest Alabama and Mississippi Barrier Islands, USA. J. Coast. Res. 2001, 17, 443-458.

(C) 2016 by the authors; licensee MDPI, Basel, Switzerland. This article is an open access article distributed under the terms and conditions of the Creative Commons Attribution (CC-BY) license (http://creativecommons.org/licenses/by/4.0/). 